\title{
Adult Hepatocytes Are Hedgehog-Responsive Cells in the Setting of Liver Injury
}

\section{Evidence for Smoothened-Mediated Activation of NF-кB/Epidermal Growth Factor Receptor/Akt in Hepatocytes that Counteract Fas-Induced Apoptosis}

Ying Wang, ${ }^{* \dagger}$ Weina Chen, ${ }^{*}$ Chang Han, ${ }^{*}$ Jinqiang Zhang, ${ }^{*}$ Kyoungsub Song, ${ }^{*}$ Hyunjoo Kwon, ${ }^{*}$ Srikanta Dash, ${ }^{*}$ Lu Yao, ${ }^{*}$ and Tong $\mathrm{Wu}^{*}$

From the Department of Pathology and Laboratory Medicine,* Tulane University School of Medicine, New Orleans, Louisiana; and the Department of Gastroenterology and Internal Medicine, ${ }^{\dagger}$ Tongji Hospital, Tongji Medical College, Huazhong University of Science and Technology, Wuhan, China

Accepted for publication July 24, 2018.

Address correspondence to Tong Wu, M.D., Ph.D., Department of Pathology and Laboratory Medicine, Tulane University School of Medicine, 1430 Tulane Ave, SL-79, New Orleans, LA 70112. E-mail: twu@tulane.edu.

\begin{abstract}
Although hedgehog $(\mathrm{Hh})$ signaling pathway is inactive in adult healthy liver, it becomes activated during acute and chronic liver injury and, thus, modulates the reparative process and disease progression. We developed a novel mouse model with liver-specific knockout of Smoothened (Smo LKO), and animals were subjected to Fas-induced liver injury in vivo. Results showed that Smo deletion in hepatocytes enhances Fas-induced liver injury. Activation of Hh signaling in hepatocytes in the setting of Fas-induced injury was indicated by the fact that Jo2 treatment enhanced hepatic expression of Ptch1, Smo, and its downstream target Gli1 in control but not Smo LKO mice. Primary hepatocytes from control mice showed increased Hh signaling activation in response to Jo2 treatment in vitro. On the other hand, the Smo KO hepatocytes were devoid of Hh activation and were more susceptible to Jo2-induced apoptosis. The levels of NF- $\kappa B$ and related signaling molecules, including epidermal growth factor receptor and Akt, were lower in Smo KO livers/hepatocytes than in control livers/hepatocytes. Accordingly, hydrodynamic gene delivery of active NK- $\kappa$ B prevented Jo2-induced liver injury in the Smo LKO mice. Our findings provide important evidence that adult hepatocytes become responsive to $\mathrm{Hh}$ signaling through up-regulation of Smo in the setting of Fas-induced liver injury and that such alteration leads to activation of NF- $\kappa \mathrm{B} / \mathrm{epidermal} \mathrm{growth} \mathrm{factor}$ receptor/Akt, which counteracts Fas-induced hepatocyte apoptosis. (Am J Pathol 2018, 188: 2605-2616; https://doi.org/10.1016/j.ajpath.2018.07.018)
\end{abstract}

The hedgehog (Hh) signaling pathway plays an important role in embryonic development and in the regulation of a variety of cellular functions, including proliferation, survival, migration, differentiation, and maintenance of progenitor cells. ${ }^{1}$ Although the Hh pathway is quiescent in normal liver, it becomes reactivated as a repair mechanism in acute and chronic liver injuries and diseases. ${ }^{1}$ Although healthy livers express low levels of Hh ligands, ${ }^{2-4}$ liver injury enhances the production of Hh ligands from several types of resident cells (including hepatocytes, cholangiocytes, hepatic stellate cells, natural killer $\mathrm{T}$ cells, and sinusoidal endothelial cells); this process is mediated by various growth factors and cytokines as well as by cytotoxic and apoptotic stresses. The produced Hh ligands are released into the local environment, where they activate the receptors on Hh-responsive cells (including progenitor cells, hepatic stellate cells, and biliary epithelial cells), which mediates liver tissue remodeling and repair. For example, Hh ligands can serve as viability and proliferative

Supported by NIH grants CA106280 and CA102325 (T.W.).

Y.W. and W.C. contributed equally to this work.

Disclosures: None declared. 
factors for liver epithelial progenitors, which are important for liver tissue repair. ${ }^{5-7}$ Hh ligands also promote the growth and viability of hepatic stellate cells/myofibroblasts and contribute to liver fibrosis and cirrhosis. ${ }^{1,8-12}$ Considering these mechanistic aspects, it is not surprising that Hh pathway activation has been shown to play a role in liver regeneration during partial hepatectomy ${ }^{13}$ and contribute to the pathogenesis of several liver diseases, including nonalcoholic fatty liver disease, ${ }^{14,15}$ alcoholic liver disease, ${ }^{16}$ and hepatocellular carcinoma. $^{17-23}$ Therefore, delineation of Hh actions in liver cells will help further understand the pathogenesis of liver diseases and provide new therapeutic implications.

The Hh signaling pathway is activated on the binding of Hh ligands (Sonic Hh, Indian Hh, and Desert Hh) to their receptor, Ptch. In the absence of Hh ligands, Ptch inhibits Smoothened (Smo), a seven-pass membrane protein that belongs to the G-protein-coupled receptor superfamily. ${ }^{24}$ Binding of Hh ligands to Ptch causes activation of Smo, which subsequently activates the Gli family of transcription factors, leading to expression of Hh target genes. Activation of transcription by the Glis is referred to as the canonical $\mathrm{Hh}$ signaling pathway, whereas those not requiring Smo or those downstream of Smo that do not require the Gli transcription faction are collectively referred to as the noncanonical Hh signaling pathway. ${ }^{25,26}$

In the liver, the nonparenchymal cells (including hepatic stellate cells and natural killer T cells) and cholangiocytes are known to produce $\mathrm{Hh}$ ligands in the setting of liver injury. The adult healthy hepatocytes produce a low amount of Hh ligands, ${ }^{27}$ although dying or ballooning hepatocytes are known to produce large amounts of Shh ligands. ${ }^{7,28}$ The Hh-responsive cells in the liver include progenitor cells, hepatic stellate cells, and biliary epithelial cells, whereas normal adult hepatocytes are considered to be nonresponsive to Hh ligands. ${ }^{1}$ However, the latter viewpoint has been challenged by a recent study showing that there is ciliaindependent but Smo-dependent signaling in mature healthy hepatocytes and that the Hh signaling is detectable in healthy mature hepatocytes. ${ }^{29}$ To date, the status and impact of $\mathrm{Hh}$ signaling in hepatocytes, particularly in the setting of liver injury, remain largely unknown.

The current study was designed to determine the role of $\mathrm{Hh}$ signaling in hepatocytes in the setting of Fas-induced liver injury. We developed a novel mouse model with liverspecific knockout of Smo, and the animals were subjected to Fas-induced liver injury to document the status of $\mathrm{Hh}$ signaling and the extent of liver injury. Our findings provide novel evidence for an important role of hepatocyte $\mathrm{Hh}$ signaling, which counteracts Fas-induced liver injury.

\section{Materials and Methods}

\section{Animal Experiments}

Homozygous floxed Smo $\left(S m o^{\text {flox/flox }} ; S m o^{\text {tm } 2 A m c} / \mathbf{J}\right)$ mice and albumin (Alb)-Cre transgenic [B6.Cg-Tg (Alb-cre) 21Mgn/J] mice were obtained from the Jackson Laboratory (Bar Harbor, ME). Smo flox/flox mice were bred to Alb-cre mice and the offspring carried a floxed Smo allele and Alb-cre $\left(\mathrm{Smo}^{f l o x / w t}: \mathrm{Alb}-\mathrm{Cr} \mathrm{e}^{+/-}\right)$. Then, Smo ${ }^{\text {flox/wt }}: \mathrm{Alb}-\mathrm{Cr} \mathrm{C}^{+/-}$mice were bred with $S m o^{\text {flox/flox }}$ mice to obtain $S m o^{\text {flox/flox }}: A l b$ $\mathrm{Cre}^{+/-} ; \quad \mathrm{Smo}^{\text {flox/flox }}: \mathrm{Alb}-\mathrm{Cre}^{-/-} ; \quad \mathrm{Smo}^{\text {flox/wt }}: \mathrm{Alb}-\mathrm{Cr} \mathrm{C}^{+/-}$ and $\mathrm{Smo}^{\text {flox/wt }}: \mathrm{Alb}-\mathrm{Cr} \mathrm{C}^{-/-}$mice (Figure 1A). We used $\mathrm{Smo}^{\text {flox/flox }}: \mathrm{Alb}-\mathrm{Cr} e^{+/-}$mice as liver-specific knockout of Smo (Smo LKO); their matched littermates $S m o^{\text {flox/flox }}: A l b$ $\mathrm{Cr}^{-/-}$and $\mathrm{Smo}^{\text {flox/wt }}: \mathrm{Alb}-\mathrm{Cr} \mathrm{C}^{-/-}$were used as control mice. Eight-week-old male mice were used in this study. The mice were kept at $22^{\circ} \mathrm{C}$ under a 12-hour light/dark cycle and received food and water freely. All of the breeding and handling of the mice and all experimental procedures were approved by the Institutional Animal Care and Use Committee of Tulane University (New Orleans, LA).

To determine the survival rate, 8 -week-old male Smo LKO and control mice were injected intraperitoneally with $0.30 \mu \mathrm{g} / \mathrm{g}$ of body weight Jo2 (anti-Fas antibody; BD Bioscience, Franklin Lakes, NJ) (Jo2 was prepared in a sterile $1 \times$ Dulbecco's phosphate-buffered saline; SigmaAldrich, St. Louis, MO); after Jo2 injection, the mice were observed continuously for up to 24 hours to assess mortality. For other experiments, the mice were injected intraperitoneally with $0.30 \mu \mathrm{g} / \mathrm{g}$ of body weight $\mathrm{Jo} 2$ and sacrificed at 3 hours after Jo2 injection; blood was collected from mouse orbital sinus according to the standard procedure; liver tissue samples were collected for histology analysis.

\section{Hydrodynamic Tail Vein Injection}

Eight-week-old male Smo LKO and control mice were anesthetized with an i.p. injection of ketamine/xylazine (80/10 $\mathrm{mg} / \mathrm{kg}$; Sigma-Aldrich). Bioseb's Mouse Tail Illuminator (Bioseb Company, Vitrolles, France) was provided by the Central Animal Facility at Tulane University Health Sciences Center. The anesthetized mouse was placed into the restraining tube. Tail vein injections were performed by using a 27-gauge needle (BD, Franklin Lakes, NJ). Each mouse was injected with $10 \%$ volume/body weight of EGFP empty control plasmid (20 $\mu \mathrm{g} / \mathrm{mL}$; Addgene, Cambridge, MA) or EGFP P65 plasmid ( $20 \mu \mathrm{g} / \mathrm{mL}$; Addgene) within 10 seconds. Twenty-four hours after tail vein injection, the mice were intraperitoneally administered Jo2, $0.30 \mu \mathrm{g} / \mathrm{g}$ of body weight. Three hours after Jo2 injection, the mice were sacrificed. Blood and liver tissue samples were collected for further analyses.

\section{Serum Parameter Analysis}

As previously described, ${ }^{30}$ blood samples were centrifuged at $800 \times g$ for 15 minutes, and the sera were collected and then stored at $-80^{\circ} \mathrm{C}$. Serum alanine aminotransferase and aspartate aminotransferase activities were measured with an automatic analyzer at the Department of Clinical Chemistry, Tulane University Hospital. 
A<smiles>[Mg][Mg][Mg][Mg]</smiles>

$\begin{array}{rll}\text { Smo flox/wt } A l b-C r e^{+/-} & \times & \text {Smo flox/flox } \\ \downarrow & \downarrow & \\ \downarrow & \downarrow\end{array}$

Smo flox/flox: Smoflox/flox: Smo flox/wt: Smoflox/wt:

$\mathrm{Alb}-\mathrm{Cre}^{+/} \quad \mathrm{Alb}-\mathrm{Cre}^{-/} \quad \mathrm{Alb}-\mathrm{Cr} \mathrm{C}^{+/-} \quad \mathrm{Alb}-\mathrm{Cre}^{-/}$
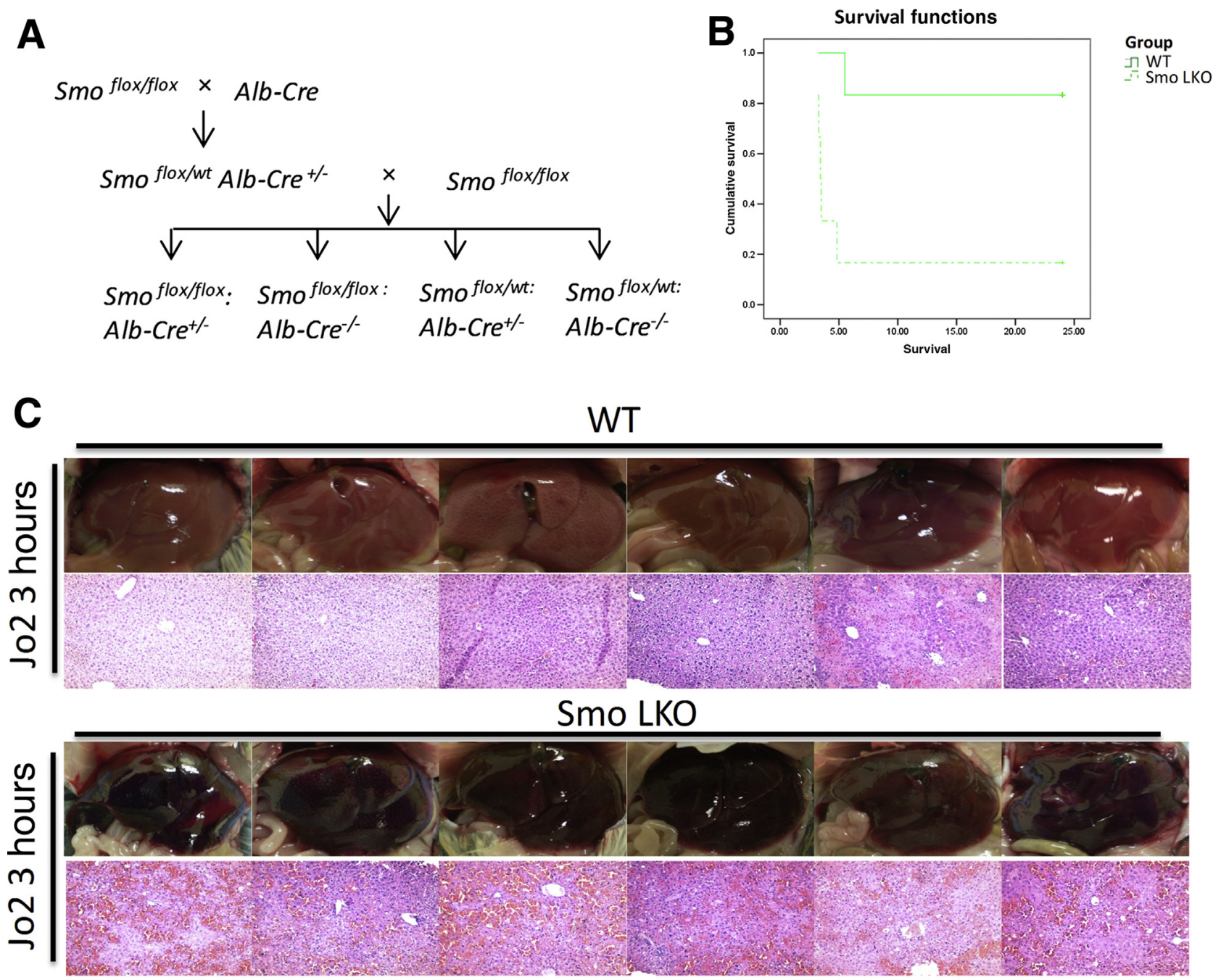

D
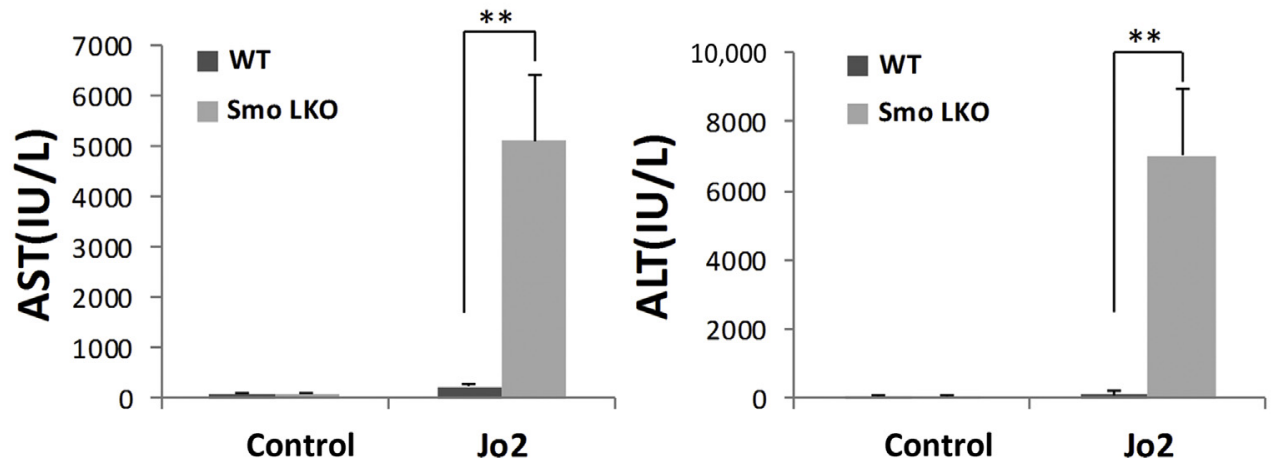

Figure 1 Liver-specific deletion of Smo enhances Fas-induced liver injury. A: Schematic diagram showing breeding strategy to generate liver-specific deletion of Smo. Smoflox/flox:Alb-Cre ${ }^{+/-}$mice were used as Smo LKO mice; their matched littermates Smo flox/flox $:$Alb-Cre $^{-/-}$ and $S m o^{\text {flox } / \mathrm{wt}}: \mathrm{Alb}-\mathrm{Cre}^{-/-}$were used as controls. B: Survival rates of Smo LKO and control mice. The mice were intraperitoneally injected with $0.30 \mu \mathrm{g} / \mathrm{g}$ of body weight Jo2. The Smo LKO mice exhibited significantly higher mortality (five of seven mice died within 5 hours, two of seven mice survived; mortality rate $=71 \%$ ) compared with the control mice (one of seven mice died at 7 hours, six of seven mice survived; mortality rate $=14 \%$ ) $(P=0.01)$. C: Gross and microscopic images of livers. Smo LKO and control mice were intraperitoneally injected with $0.30 \mu \mathrm{g} / \mathrm{g}$ of body weight Jo2, and the animals were sacrificed 3 hours after Jo2 injection. Although the control livers appeared normal under gross examination, the Smo LK0 livers turned dark red because of hemorrhage. Histologic examination showed more prominent liver tissue damage in Smo LKO livers compared with the control livers (hematoxylin and eosin stain). D: Serum aspartate aminotransferase (AST) and alanine aminotransferase (ALT) levels increase in Smo LKO mice compared with control mice. Data are expressed as means \pm SD (D). $n=7$ per group (B); $n=6$ per group (C). ${ }^{* *} P<0.01$. Original magnification, $\times 100$ (C). WT, wild type. 


\section{Histopathological Analysis}

The liver tissue samples were fixed with $10 \%$ buffered formalin and embedded in paraffin. Sections $(5 \mu \mathrm{m}$ thick) were affixed to slides, deparaffinized, and stained with hematoxylin and eosin. Light microscopy was performed to assess the morphologic changes.

\section{Terminal Deoxynucleotidyl Transferase-Mediated dUTP Nick-End Labeling Assay}

Detection of apoptotic cells in liver tissue was performed by In Situ Cell Death Detection Kit, Fluorescein (Roche, Indianapolis, IN), according to the manufacturer's protocol. Paraffinembedded liver tissue sections were dewaxed in xylene twice (5 minutes each time), hydrated in 100\% ethanol for 2 minutes, and washed in decreasing concentrations of ethanol $(95 \%$, $90 \%, 80 \%$, and $70 \%$ ). The tissue sections were incubated for 30 minutes at room temperature with Proteinase $\mathrm{K}$ working solution $(20 \mu \mathrm{g} / \mathrm{mL}$ in $10 \mathrm{mmol} / \mathrm{L}$ Tris/ $\mathrm{HCl}, \mathrm{pH} 7.4$ to 8$)$. The slides were rinsed twice with $1 \times$ phosphate-buffered saline (Sigma-Aldrich). Terminal deoxynucleotidyl transferasemediated dUTP nick-end labeling reaction mixture $(50 \mu \mathrm{L})$ was added to each sample ( $50 \mu \mathrm{L}$ label solution was used for negative control). The slides were incubated in a humidified atmosphere for 60 minutes at $37^{\circ} \mathrm{C}$ in the dark. After rinsing with $1 \times$ phosphate-buffered saline for three times, the slides were directly analyzed under a fluorescence microscope using a wavelength at 450 to $500 \mathrm{~nm}$.

\section{Cleaved Caspase-3 Staining}

Paraffin-embedded liver tissue sections were stained with cleaved caspase- 3 antibody (Biocare Medical, Pike Lane Concord, CA), which specifically recognizes the large fragment $(17 / 19 \mathrm{kDa})$ of activated caspase-3. The liver tissue sections were deparaffinized by immersing sections in xylene for 10 minutes and hydrated through ethanol to running water. Sections were processed for heat-induced epitope retrieval. After blocking with Biocare's Peroxidazed 1 (Biocare Medical) for 5 minutes, the sections were incubated for 1 hour at room temperature with rabbit polyclonal antibody against cleaved caspase-3. After washing three times in tris-buffered saline, the sections were incubated with horseradish peroxidase-conjugated goat anti-rabbit IgG (1:10,000; Abcam, Cambridge, MA) for 1 hour at room temperature. After washing in tris-buffered saline, diaminobenzidine-horseradish peroxidase substrate was then added for color development.

\section{Real-Time Quantitative RT-PCR}

Total RNA was extracted from liver tissues and hepatocytes using Trizol (Invitrogen, Grand Island, NY). For first-strand cDNA synthesis, $1 \mu \mathrm{g}$ total RNA was reverse transcribed using Qiagen miScript reverse transcription kit (Qiagen,
Valencia, CA). Primers were synthesized at IDT (Coralville, IA) as follows: Smo, $5^{\prime}$-ACCTATGCCTGGCACACTTC- $3^{\prime}$ (forward) and 5'-GTGAGGACAAAGGGGAGTGA-3' (reverse); Ptch1, 5'-CTGTCAAGGTGAATGGAC-3' (forward) and 5'-GGGGTTATTCTGTAAAAGG-3' (reverse); Gli1, 5'-GCTGTCGGAAGTCCTATT-3' (forward) and 5'ACTGGCATTGCTAAAGG- $3^{\prime}$ (reverse); and $18 \mathrm{~S}$, 5'CGCTTCCTTACCTGGTTGAT- $3^{\prime}$ (forward) and $5^{\prime}$ GAGCGACCAAAGGAACCATA-3' (reverse). The miScript SYBR Green PCR Kit (Qiagen) and the CFX96 Touch Real-Time PCR Detection System (Bio-Rad, Hercules, CA) were used. The data were analyzed by using CFX Manager software version 3.1 (Bio-Rad), and the results were normalized to $18 \mathrm{~S}$ ribosomal RNA.

\section{Hepatocyte Isolation and Culture}

Hepatocytes were isolated from male Smo LKO and control mice by an adaptation of the calcium two-step collagenase perfusion technique, as described previously. ${ }^{31}$ Cells were plated onto collagen-coated 10-cm dishes (BD Biosciences, San Jose, CA) at a density of $3 \times 10^{6}$ cells. The cultures were maintained in Williams' Medium E medium (Invitrogen) supplemented with Hepatocyte Maintenance Supplement Pack (Invitrogen), 10\% fetal calf serum (Sigma-Aldrich), 2 $\mathrm{mmol} / \mathrm{L} \mathrm{L}$-glutamine (Invitrogen), and antibiotic-antimycotic (Invitrogen). After 2 hours to allow for attachment, the hepatocyte cultures were washed with $1 \times$ phosphate-buffered saline and then incubated for 4 hours with media containing $0.50 \mu \mathrm{g} / \mathrm{mL}$ Jo2 plus $10 \mu \mathrm{g} / \mathrm{mL}$ cycloheximide (Sigma-Aldrich).

\section{Western Blot Analysis}

Western blot analysis was performed according to standard procedures. Primary antibodies against caspase-3, caspase-7, caspase-8, cleaved caspase-8, caspase-9, cleaved caspase-9, poly (ADP-ribose) polymerase, NF- $\kappa \mathrm{B}, \mathrm{p}-\mathrm{NF}-\kappa \mathrm{B}$ (Ser536), epidermal growth factor receptor (EGFR), Akt, p-Akt (Ser473), 4E-binding protein 1, and p-4E-binding protein 1 were obtained from Cell Signaling Technology (Beverly, MA); primary antibody against glyceraldehyde-3-phosphate dehydrogenase was obtained from Ambion (Austin, TX); goat anti-rabbit or goat anti-mouse secondary antibodies were purchased from LI-COR Biosciences (Lincoln, NE). Results were analyzed by LI-COR Odyssey (Lincoln, NE).

\section{Nuclear Extract}

Nuclear extract was obtained using CelLytic NuCLEAR Extraction Kit (Sigma-Aldrich). Specifically, $100 \mathrm{mg}$ liver tissue was homogenized in $500 \mu \mathrm{L} 1 \times$ Lysis Buffer (containing $1 \mathrm{mmol} / \mathrm{L}$ dithiothreitol and protease inhibitor cocktail) using the PT 1200 E Homogenizer (Kinematica, Bohemia, NY) until $>90 \%$ of the cells are broken and nuclei are visualized under a microscope. The samples were then 
centrifuged at $11,000 \times g$ for 20 minutes at $4^{\circ} \mathrm{C}$. The supernatant was transferred to a fresh tube (collected as cytoplasmic fraction). The crude nuclei pellets were resuspended in $0.67 \times$ packed cell volume of Extraction Buffer (containing $1 \mathrm{mmol} / \mathrm{L}$ dithiothreitol and protease inhibitor cocktail), followed by homogenization using a 27 -gauge needle (BD) on ice. The samples were shaken gently for 30 minutes and then centrifuged at $20,000 \times g$ for 5 minutes at $4^{\circ} \mathrm{C}$; the supernatant was collected as nuclear extract.

\section{DNA-Protein Pull-Down Assay}

Biotinylated and nonbiotinylated EGFR primers were synthesized at IDT. Probes for DNA-protein pull-down assays were generated by annealing biotinylated (or nonbiotinylated) EGFR primers as follows: $5^{\prime}$-end biotinylated EGFR forward primer ( $5^{\prime}$-biotin-GGAACGCCCC-3') and $5^{\prime}$-end biotinylated EGFR reverse primer (5'-biotinGGGGCGTTCC $-3^{\prime}$ ). The primers were diluted to a concentration of $2 \mu \mathrm{g} / \mu \mathrm{L} ; 45 \mu \mathrm{L}$ of each primer was mixed with $10 \mu \mathrm{L}$ annealing buffer $(10 \mathrm{mmol} / \mathrm{L}$ HEPES, $\mathrm{pH}$ 7.9, 100 $\mathrm{mmol} / \mathrm{L} \mathrm{KCL}, 5 \mathrm{mmol} / \mathrm{L} \mathrm{MgCl}_{2}, 10 \%$ glycerol, $1 \mathrm{mmol} / \mathrm{L}$ dithiothreitol, and $0.5 \% \mathrm{NP} 40$ ). The solution was incubated at $95^{\circ} \mathrm{C}$ for 2 minutes, followed by slowly cooling to room temperature (the nonbiotinylated EGFR forward and reverse primers were annealed through the same process). For DNA-protein pull-down assay, a total of $2 \mu \mathrm{g}$ nuclear protein was incubated with $1 \mu \mathrm{g}$ annealed biotin-labeled EGFR probe and $10 \mu \mathrm{g}$ poly (deoxyinosinic-deoxycytidylic) acid sodium (Sigma-Aldrich) in $500 \mu \mathrm{L}$ HKMG buffer (10 $\mathrm{mmol} / \mathrm{L}$ HEPES, pH 7.9, $100 \mathrm{mmol} / \mathrm{L} \mathrm{KCL}, 5 \mathrm{mmol} / \mathrm{L}$ $\mathrm{MgCl}_{2}, 10 \%$ glycerol, $1 \mathrm{mmol} / \mathrm{L}$ dithiothreitol, and $0.5 \%$ NP40) on a rocker platform (VWR, Radnor, PA) at $4^{\circ} \mathrm{C}$ overnight. As negative control, a total of $2 \mu \mathrm{g}$ nuclear protein was incubated with $1 \mu \mathrm{g}$ annealed biotin-labeled EGFR probe, $20 \mu \mathrm{g}$ annealed non-biotin-labeled EGFR probe, and $10 \mu \mathrm{g}$ poly (deoxyinosinic-deoxycytidylic) acid sodium (Sigma-Aldrich) in $500 \mu \mathrm{L}$ HKMG buffer at $4^{\circ} \mathrm{C}$ overnight. Protein A/G PLUS-Agarose beads ( $20 \mu \mathrm{L}$; Santa Cruz Biotechnology, Dallas, TX) were then added, and the samples were incubated at $4^{\circ} \mathrm{C}$ for 1 hour. The immunoprecipitates were collected by centrifugation at $1000 \times g$ for 5 minutes at $4^{\circ} \mathrm{C}$. The pellets were washed twice with $1 \mathrm{~mL}$ $1 \times$ phosphate-buffered saline by centrifugation at $1000 \times g$ for 5 minutes at $4^{\circ} \mathrm{C}$. After a final wash, the pellet was resuspended in $20 \mu \mathrm{L} 1 \times$ electrophoresis sample buffer (Bio-Rad), and the samples were subjected to SDS-PAGE and Western blot analysis.

\section{Statistical Analysis}

Data are presented as means \pm SD. Differences between two groups were determined by a two-tailed $t$-test. KaplanMeier survival analysis (log-rank) was used for mortality analysis. The statistical analyses were performed using
Sigma Stat software version 3.5 (Systat Software, Inc., San Jose, CA). $P<0.05$ was considered statistically significant.

\section{Results}

Liver-Specific Deletion of Smo Enhances Fas-Induced Liver Injury

To produce mice with Smo LKO, Smo ${ }^{f l o x / w t}: A l b-C r e^{+/-}$ mice were crossed with $S m o^{f l o x / f l o x}$ mice (Figure 1A). The resulting $\mathrm{Smo}^{f l o x / f l o x}: \mathrm{Alb}-\mathrm{Cr} e^{+/-}$offsprings were used as Smo LKO mice; their matched littermates $\left(S m o^{f l o x f f o x}: A l b-\right.$ $\mathrm{Cr}^{-/-}$and $\mathrm{Smo}^{f l o x / w t}: \mathrm{Alb}-\mathrm{Cr}^{-/-}$) were used as controls. To assess whether liver-specific deletion of Smo would affect Fas-induced acute liver injury, 8-week-old male Smo LKO and matched control mice were injected intraperitoneally with a single dose of the anti-Fas antibody Jo2 $(0.30 \mu \mathrm{g} / \mathrm{g}$ of body weight), and the animals were closely monitored for survival. The Smo LKO mice exhibited significantly higher mortality compared with the control mice $(P=0.01)$ (Figure 1B). To further document the extent of liver injury, separate groups of Smo LKO and matched control mice were subjected to Jo2 treatment (at the same dose), and the animals were sacrificed at 3 hours to obtain blood and liver tissue samples. Although the livers of control mice appeared normal on gross examination, the livers of Smo LKO mice turned dark red (Figure 1C). Histologic examination of the liver tissues under hematoxylin and eosin staining revealed more prominent parenchymal hemorrhage and more hepatocyte apoptosis in the livers of Smo LKO mice compared with the livers of control mice (Figure 1C). Accordingly, the levels of serum aspartate aminotransferase and alanine aminotransferase in Jo2-treated Smo LKO mice were significantly higher than in Jo2-treated control mice (Figure 1D). These findings demonstrate that Smo deletion in hepatocytes enhances Fas-induced liver injury.

Activation of Fas by its ligand (or antibody Jo2) is known to cause the formation of the death-inducing signaling complex, which recruits and activates caspase-8, leading to subsequent activation of caspase-3/7 and caspase-9; such caspase cascade activation finally results in apoptosis. Therefore, apoptotic parameters were further analyzed in the liver tissues harvested from Jo2-treatd Smo LKO and control mice (3 hours after Jo2 injection). The number of terminal deoxynucleotidyl transferase-mediated dUTP nick-end labeling-positive hepatocytes in Smo KO livers was significantly higher compared with control livers (Figure 2A). Under immunohistochemical staining for cleaved caspase-3, the Smo KO livers showed a higher percentage of cleaved caspase-3-positive hepatocytes and stronger staining intensity compared with the control livers (Figure 2B). Under Western blot analysis, the Smo KO livers showed more prominent cleavage of caspases $3 / 7,8$, and 9 and poly (ADP-ribose) polymerase compared with the control livers (Figure 2C). These findings indicate more prominent caspase activation in the liver tissues from Jo2-treated Smo LKO mice compared with Jo2-treated control mice. 
Hepatocyte Hh Signaling Is Activated during Fas-Induced Apoptosis

Although Hh signaling is inactive in normal adult livers, this pathway becomes activated during acute and chronic liver injuries, manifested by enhanced production of Hh ligands and their target genes ${ }^{4,7,13}$ as well as increased accumulation of Hh ligand-producing cells and Hh-responsive target cells. ${ }^{14,31}$ There are several types of liver cells that are known to be responsive to $\mathrm{Hh}$ ligand, including hepatic stellate cells and fibroblasts, ${ }^{32}$ liver progenitor cells, ${ }^{5}$ and cholangiocytes $^{33,34}$; however, hepatocytes have been considered as $\mathrm{Hh}$ nonresponsive cells. ${ }^{16}$ Jo2 treatment significantly increased hepatic expression of Smo and its downstream targets Gli1 and Ptch1, in control mice; in contrast, this phenomenon was not observed in Smo LKO mice
(Figure 2D). These findings demonstrate that Hh signaling in the liver becomes activated in the setting of Fas-induced liver injury and that hepatocytes represent a noticeable population of cells that exhibit Hh activation under this condition.

\section{Smo Deletion Enhances Fas-Induced Liver Injury through Inhibition of the NF-KB/EGFR/Akt Pathway}

Western blot analysis was performed to determine the levels of key molecules implicated in Fas-induced liver injury. The levels of NF- $\kappa \mathrm{B}, \mathrm{p}-\mathrm{NF}-\kappa \mathrm{B}$ (Ser536), EGFR, and p-Akt (Ser473) were decreased in the liver tissues from Jo2-treated Smo LKO mice compared with Jo2-treated control mice (Figure 3A). Given the documented roles of these proteins in protection against Fas-induced apoptosis, ${ }^{35-39}$ it is likely that reduction of these molecules in Jo2-treated Smo LKO
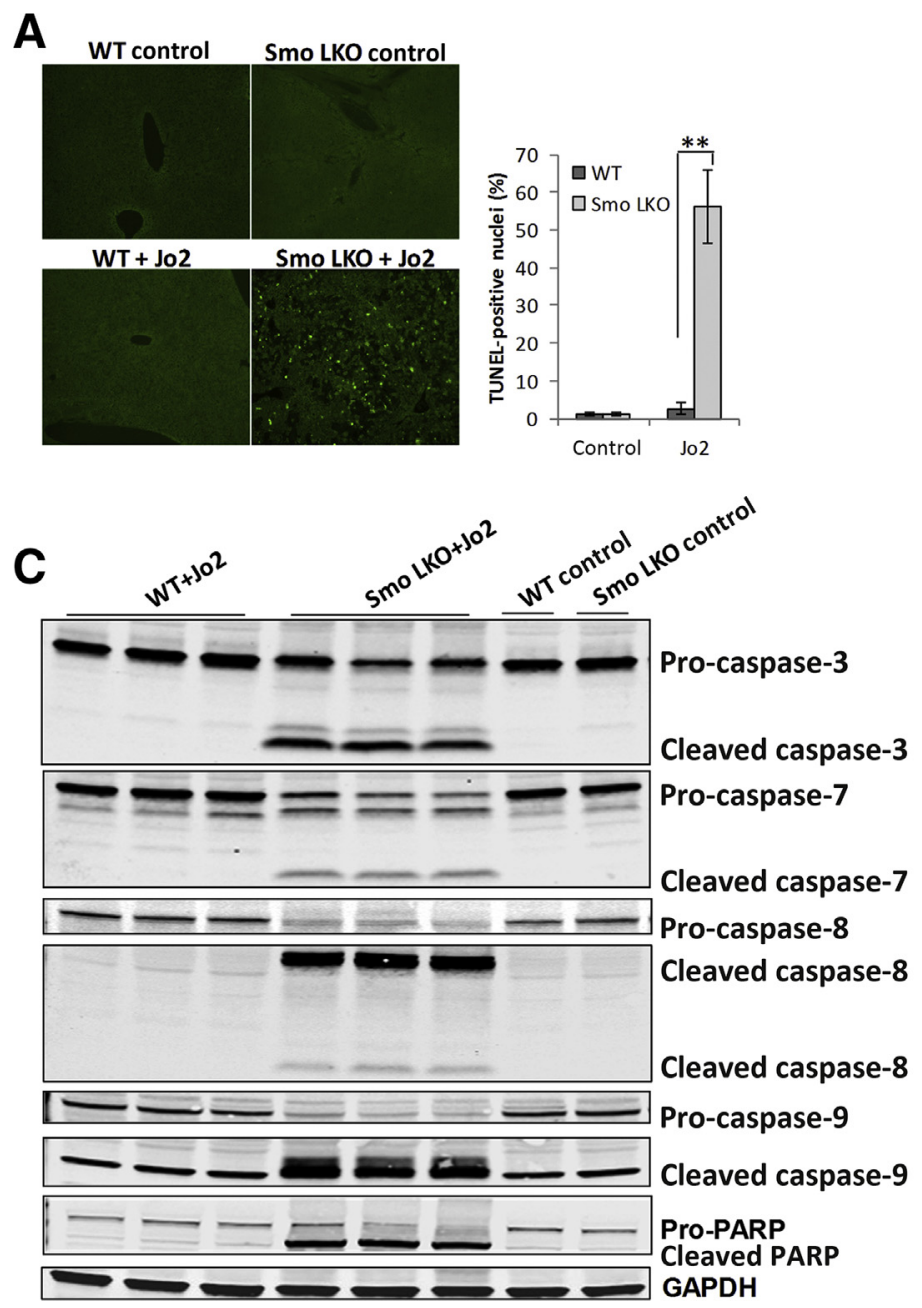

B

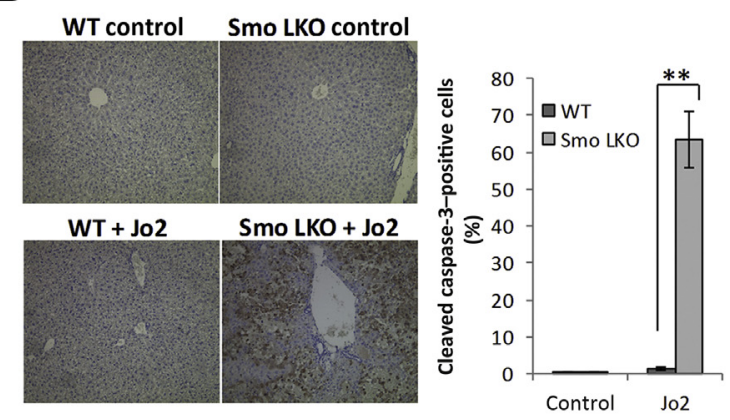

D
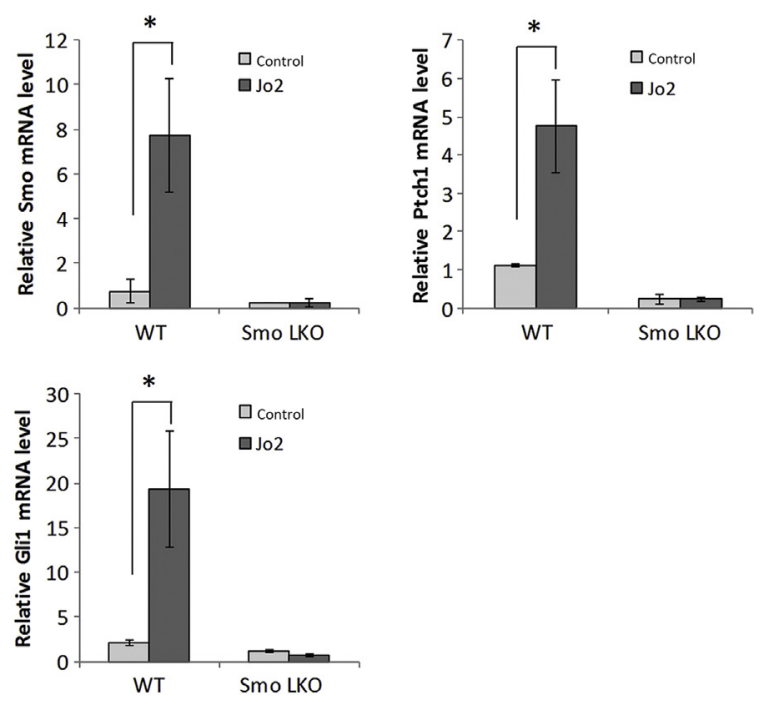

Figure 2 Smo deletion enhances Fas-induced caspase activation. A: Left panels show terminal deoxynucleotidyl transferase-mediated dUTP nick-end labeling (TUNEL) analysis of liver tissues from Smo LKO and control mice (sacrificed 3 hours after Jo2 injection). Right panel shows quantification of TUNEL-positive hepatocytes. B: Left panels show immunohistochemical stain for cleaved caspase-3. Right panel shows quantification of cleaved caspase3-positive hepatocytes. C: Western blot analysis for caspases 3, 7, 8, and 9 and poly (ADP-ribose) polymerase (PARP) in the liver tissues. D: Hh signaling pathway is activated in the control mice but not in Smo LKO mice after Jo2 injection. Real-time quantitative RT-PCR analysis for Smo, Ptch1, and Gli1 mRNAs in the liver tissues. Data are expressed as means $\pm \mathrm{SD}(\mathbf{A}, \mathbf{B}$, and $\mathbf{D}) .{ }^{*} P<0.05,{ }^{*} P<0.01$. Original magnification, $\times 100(\mathbf{A}$ and $\mathbf{B})$. GAPDH, glyceraldehyde-3phosphate dehydrogenase; WT, wild type. 
mice may contribute to the exacerbation of liver injury seen in these animals. By using the transcription binding tool Genomatix MatInspector, a putative NF- $\mathrm{BB}$ binding site was identified within -511 to -502 of the EGFR promoter. A DNA-protein pull-down assay showed that Jo2 treatment enhanced the binding of hepatic NF- $\kappa B$ to this motif in control mice, but not in Smo LKO mice (Figure 3B). These observations support the role of NF- $\kappa \mathrm{B}$ for regulation of EGFR expression in the liver. Thus, decreased NF- $\kappa \mathrm{B}$ activity may be a mechanism for reduced EGFR in Jo2treated Smo LKO mice.

Consistent with the well-documented Akt phosphorylation by the EGFR pathway, the level of p-Akt (Ser473) in the livers of Jo2-treated Smo LKO mice was lower compared with Jo2-treated control mice (Figure 3A). Accordingly, the phosphorylation of the Akt downstream target, eukaryotic translation initiation factor 4E-binding protein $1,{ }^{40}$ was markedly decreased in Jo2-treated Smo LKO mice compared with Jo2-treated control mice (Figure 3A). The above findings suggest that Smo deficiency may enhance Fas-induced liver injury through inhibition of the NF- $\kappa \mathrm{B} / \mathrm{EGFR} / \mathrm{Akt}$ pathway.

\section{Smo Deletion Enhances Fas-Induced Apoptosis in Hepatocytes, in Vitro}

To determine the role of Smo in Fas-induced hepatocyte apoptosis, primary hepatocytes were isolated from the Smo LKO and control mice, according to previously described methods. ${ }^{31}$ The hepatocyte cultures were treated with Jo2, $0.50 \mu \mathrm{g} / \mathrm{mL}$, plus cycloheximide, $10 \mu \mathrm{g} / \mathrm{mL}$, for 4 hours to determine parameters of apoptosis. Jo2 treatment induced more prominent apoptosis in Smo KO hepatocytes compared with control hepatocytes, as determined by quantitative analysis for apoptotic cells under Hoechst staining (Figure 4A). Accordingly, Jo2-induced increase of caspase-3/ 7 and caspase- 8 activities was more prominent in Smo KO hepatocytes compared with control hepatocytes (Figure 4B). These findings demonstrate that deletion of Smo in hepatocytes exacerbates Fas-induced apoptosis, in vitro.

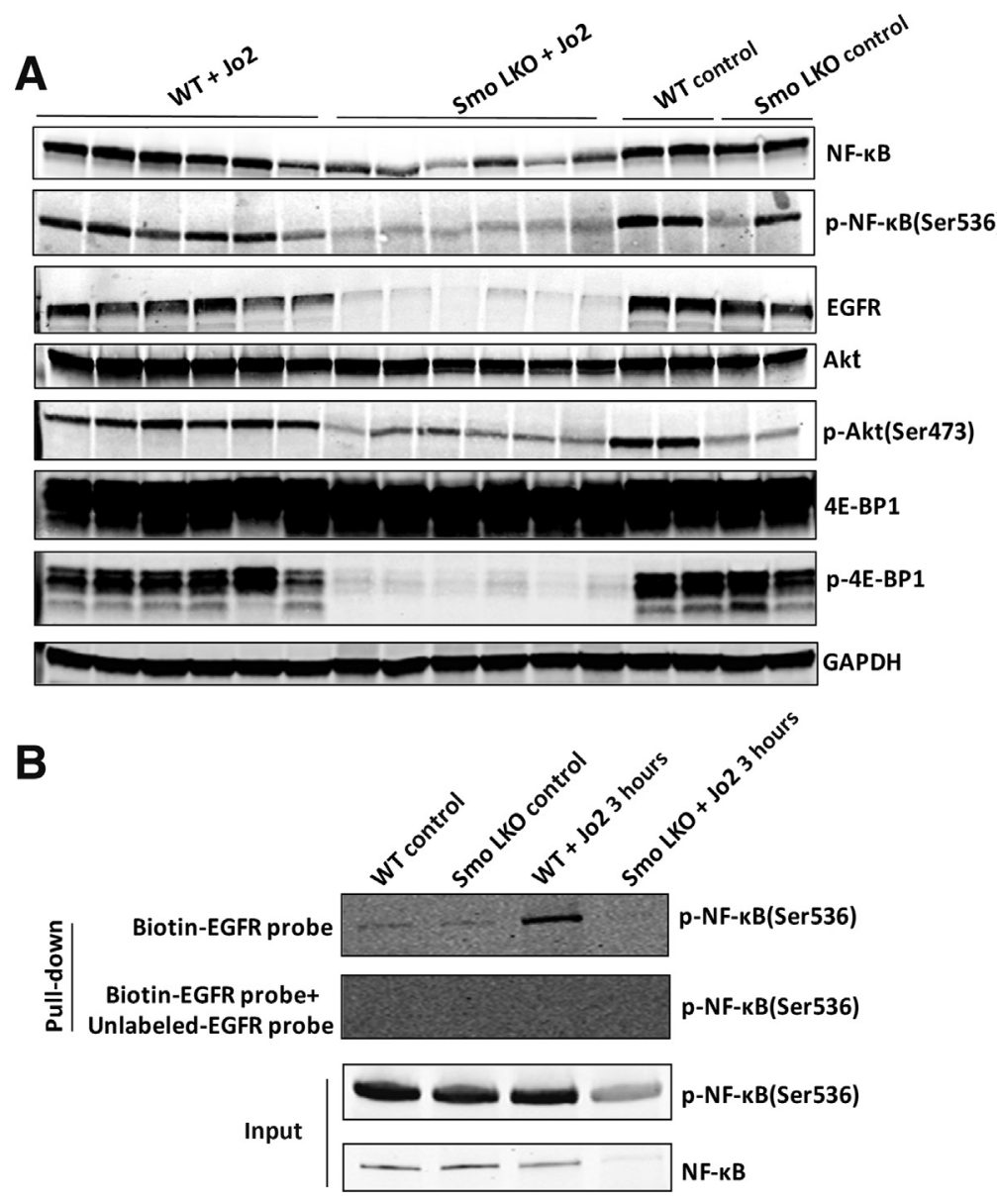

Figure 3 The impact of Smo deletion on the NF- $\mathrm{BB}$ / epidermal growth factor receptor (EGFR)/Akt pathway. Smo LKO and control mice were intraperitoneally injected with $0.30 \mu \mathrm{g} / \mathrm{g}$ of body weight Jo2. The mice were sacrificed 3 hours after Jo2 injection. A: The liver tissue lysates were subjected to Western blot analysis for indicated molecules. B: The liver nuclear extracts were processed for DNA-protein pull-down analysis. 4E-BP1, 4E-binding protein 1; GAPDH, glyceraldehyde-3-phosphate dehydrogenase; WT, wild type. 

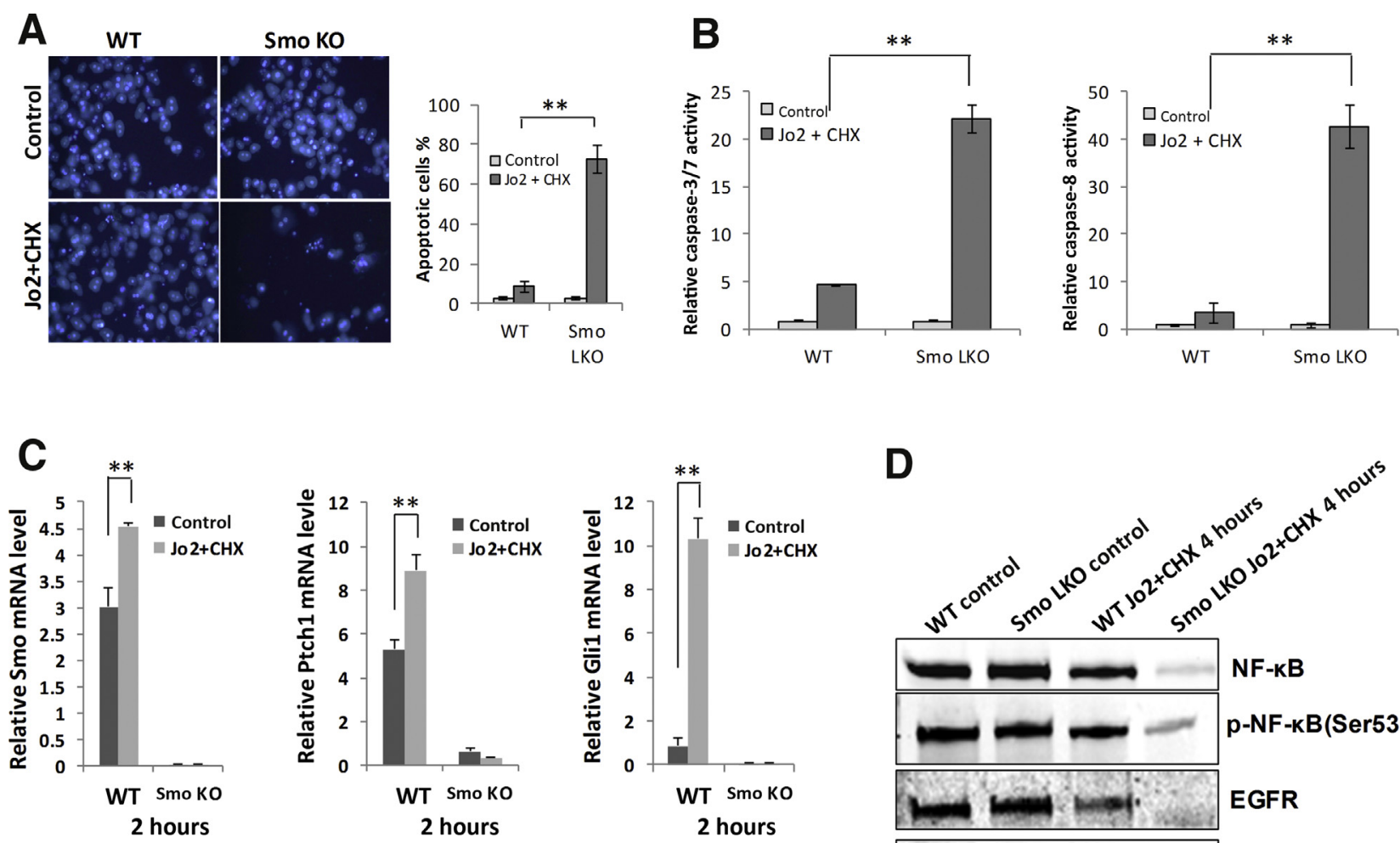

D
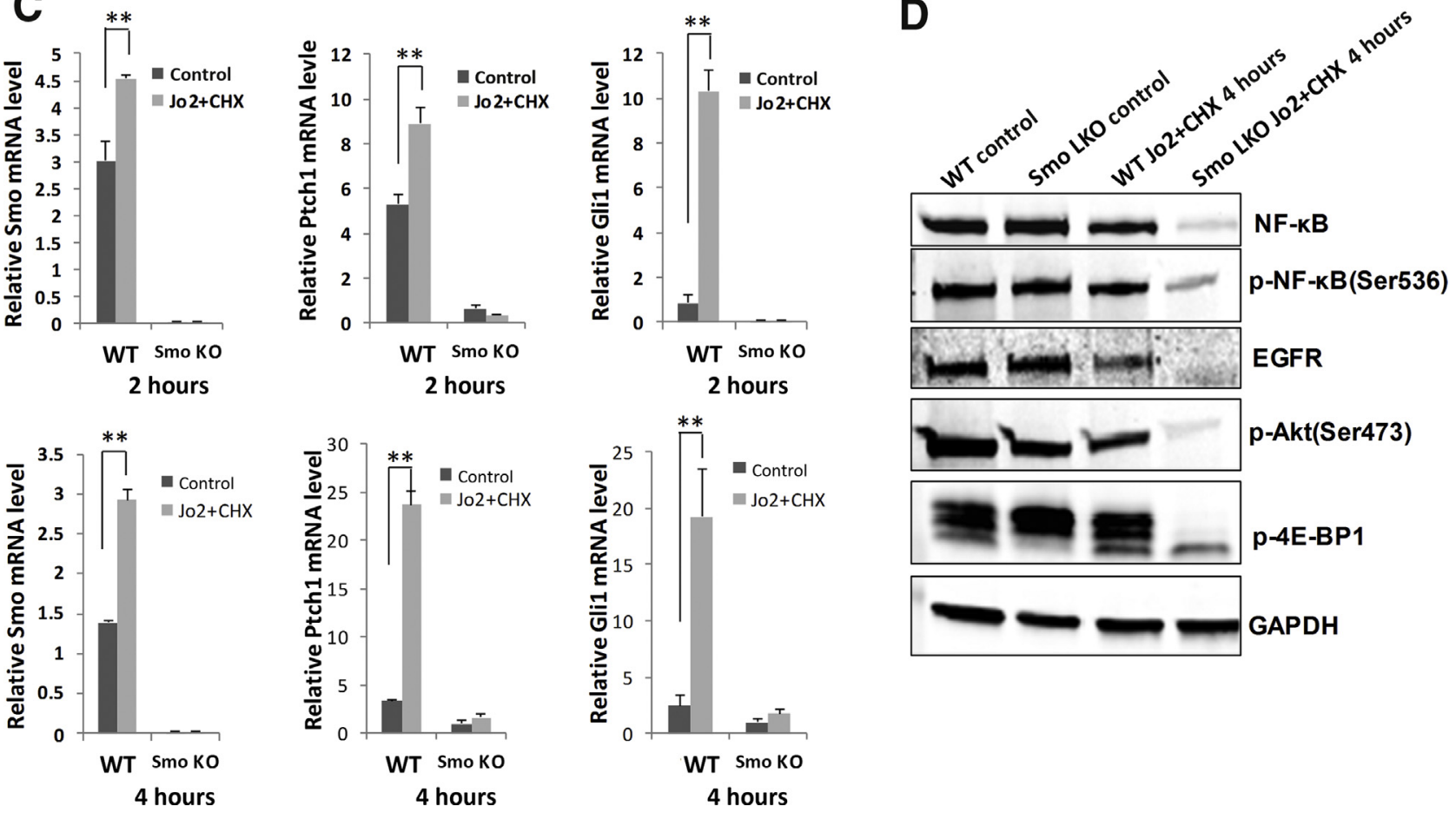

Figure 4 Smo deletion enhances Fas-induced apoptosis in hepatocytes. Primary hepatocytes were isolated from Smo LKO and control mice. The cells were treated with Jo2 $(0.50 \mu \mathrm{g} / \mathrm{mL})$ plus cycloheximide (CHX; $10 \mu \mathrm{g} / \mathrm{mL})$ for 4 hours. A: Left panels show representative Hoechst staining. Right panel shows quantitative analysis for apoptotic cells under Hoechst staining. B: Caspase-3/7 and caspase-8 activities. C: Primary hepatocytes were isolated from Smo LKO and control mice, and the cells were treated with $0.50 \mu \mathrm{g} / \mathrm{mL} \mathrm{Jo2}$ plus $10 \mu \mathrm{g} / \mathrm{mL}$ CHX for 2 or 4 hours. Real-time quantitative RT-PCR analysis was performed to determine the mRNA levels of Smo, Ptch1, and Gli1. D: Western blot analysis to detect the levels of indicated proteins in hepatocytes with indicated treatments. Data are expressed as means $\pm \mathrm{SD}(\mathbf{A}-\mathbf{C}) .{ }^{*} P<0.01$. Original magnification, $\times 200(\mathbf{A}) .4 \mathrm{E}-\mathrm{BP} 1$, 4E-binding protein 1 ; EGFR, epidermal growth factor receptor; GAPDH, glyceraldehyde-3-phosphate dehydrogenase; WT, wild type.

The Levels of Hh and Related Signaling Molecules in Hepatocytes

The expression levels of Hh signaling molecules in hepatocytes isolated from Smo LKO and control mice were further studied. The control hepatocytes treated with Jo2 showed upregulation of Smo, Ptchl, and Glil mRNAs; however, this effect was not observed in Smo KO hepatocytes under the same treatment (Figure 4C). These findings further support the notion that hepatocyte $\mathrm{Hh}$ signaling can be activated in the setting of Fas-induced injury. Consistent with these observations, Jo2 treatment led to reduction of NF- $\kappa \mathrm{B}, \mathrm{p}-\mathrm{NF}-\kappa \mathrm{B}$ (Ser536), EGFR, p-Akt (Ser473), and p-4E-binding protein 1 in Smo-deleted hepatocytes, but not in control hepatocytes (Figure 4D).

\section{Overexpression of NF- $\kappa \mathrm{B}$ Prevents Fas-Induced Liver Injury in Smo LKO Mice}

To further investigate the role of NF- $\kappa \mathrm{B}$, an active component of NF- $\mathrm{KB}$ was delivered to the livers of Smo LKO and control mice via hydrodynamic gene delivery. This was achieved by injecting $10 \%$ volume/body weight of naked p65 plasmid (20 $\mu \mathrm{g} / \mathrm{mL})$ or control empty plasmid $(20 \mu \mathrm{g} / \mathrm{mL})$ to the mice within 10 seconds through tail vein, as previously described. ${ }^{41-43}$ Successful expression of p65 in the livers was 
confirmed by Western blot analysis (24 hours after injection) (Figure 5D). Thus, in subsequent experiments, 24 hours after hydrodynamic tail vein injection of p65 or control plasmid, the mice were injected intraperitoneally with Jo2 $(0.30 \mu \mathrm{g} / \mathrm{g}$ of body weight), and the animals were sacrificed 3 hours after Jo2 injection. NF- $\kappa$ B overexpression attenuated Fas-induced liver injury in Smo LKO mice, as documented by histopathological examination of the liver tissues (Figure 5A), measurement for serum transaminases (Figure 5B), and Western blot analysis for cleaved poly (ADP-ribose) polymerase, caspase-8, and caspase-3 in the liver tissues (Figure 5C). These data indicate that NF- $\kappa \mathrm{B}$ overexpression can effectively prevent Fas-induced liver injury in Smo LKO mice. Taken together, our findings demonstrate that adult

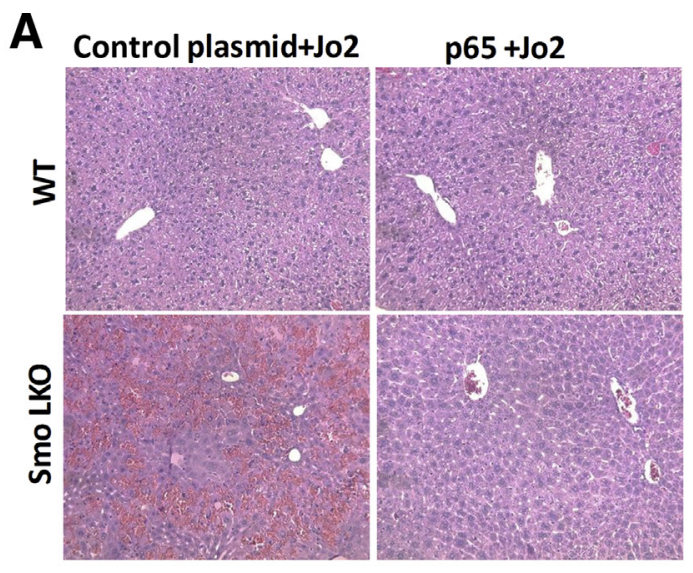

hepatocytes are responsive to $\mathrm{Hh}$ signaling in the setting of Fas-induced liver injury and that such an alteration leads to activation of NF- $\kappa \mathrm{B} / \mathrm{EGFR} / \mathrm{Akt}$, which counteracts Fasinduced hepatocyte apoptosis (Figure 5E).

\section{Discussion}

Fas (CD95/apoptosis antigen 1)-mediated apoptosis has been implicated in a broad spectrum of liver diseases from autoimmune disorders, to viral hepatitis, to fulminant hepatic failure. $^{44-46}$ The expression of Fas receptor and Fas ligand is up-regulated in patients with various liver diseases, including chronic viral hepatitis $\mathrm{B}$ and $\mathrm{C}$ infection, ${ }^{47}$ nonalcoholic

\section{B}

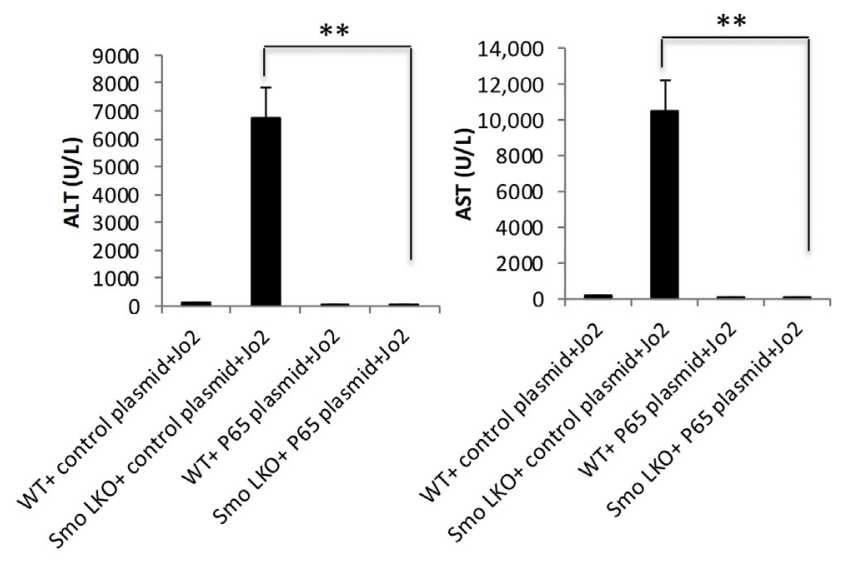

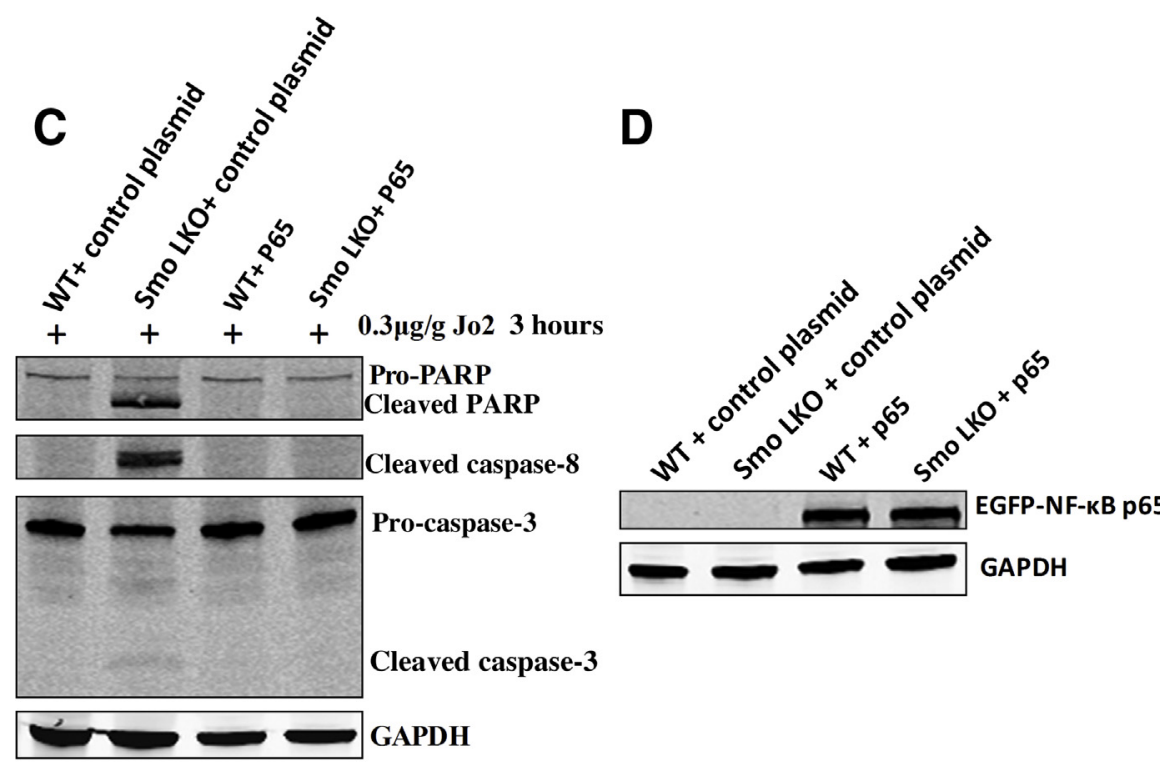

E

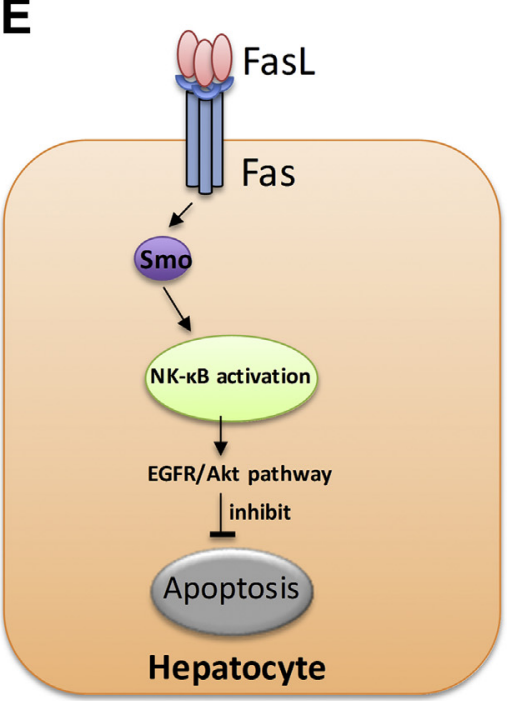

Figure 5 Overexpression of NF- $\kappa$ B prevents Fas-induced liver injury in Smo LKO mice. A: NF- $\kappa B$ overexpression prevents Fas-induced liver tissue injury in Smo LKO mice. Twenty-four hours after hydrodynamic tail vein injection of NF- $\kappa B$ or control plasmid, the mice were intraperitoneally injected with Jo2 (0.30 $\mu \mathrm{g} / \mathrm{g}$ of body weight). Three hours after Jo2 injection, the mice were sacrificed and the liver tissues were obtained and processed for histologic evaluation (hematoxylin and eosin staining). B: Serum aspartate aminotransferase (AST) and serum alanine aminotransferase (ALT) analysis. C: Western blot analysis for poly (ADP-ribose) polymerase (PARP), caspase-8, and caspase-3. D: The efficiency of NF- $\kappa$ B expression in mice receiving tail vein hydrodynamic injection of $\mathrm{NF}-\kappa \mathrm{B}$ expression plasmid $(20 \mu \mathrm{g} / \mathrm{mL})$. E: Illustration of hepatocyte Hh signaling in Fas-induced liver injury. Data are expressed as means \pm SD (B). $* * P<0.01$. Original magnification, $\times 100$ (A). EGFR, epidermal growth factor receptor; EGFP, enhanced green fluorescent protein; GAPDH, glyceraldehyde-3phosphate dehydrogenase; WT, wild type. 
steatohepatitis, $^{34}$ alcoholic liver disease, ${ }^{48}$ drug- or acetaminophen-induced liver injury, ${ }^{49}$ and acute liver failure. $^{50}$ There is clinical evidence indicating that Fas-mediated hepatocyte apoptosis is a prominent feature of patients with nonalcoholic steatohepatitis and an important trigger for the induction of human fulminant hepatic failure. ${ }^{34,50}$ In the current study, we evaluated the effect of hepatocyte Smo on Fasinduced liver injury. Our findings provide novel evidence for an important role of Hh signaling in hepatocytes for prevention of Fas-induced apoptosis and liver injury via activation of the NF- $\kappa \mathrm{B} / \mathrm{EGFR} / \mathrm{Akt}$ pathway. This assertion is based on the following lines of evidence: i) deletion of hepatocyte Smo significantly enhanced Fas-induced apoptosis, in vivo and in vitro; ii) the Hh signaling pathway became activated in the livers and hepatocytes from control mice treated with Jo2, whereas these phenomena were absent in the liver tissues and hepatocytes from Jo2-treated Smo LKO mice; and iii) the NF$\kappa \mathrm{B} / \mathrm{EGFR} / \mathrm{Akt}$ pathway was inhibited in the liver tissues and hepatocytes from Jo2-treated Smo LKO mice. To our knowledge, this is the first study to demonstrate Smomediated activation of $\mathrm{Hh}$ signaling in hepatocytes, which counteracts Fas-induced liver injury. Besides Fas-induced liver injury, our further experiments with the Smo LKO mice reveal that hepatocyte Smo also protects against lipopolysaccharide/galactosamine-induced liver injury (Supplemental Figures S1 and S2). Our results suggest that $\mathrm{Hh}$ signaling activation in hepatocytes is an important survival mechanism in response to liver injury. Conceivably, this mechanism may have important implications in the pathogenesis of human liver diseases characterized by hepatocyte injury.

Hh signaling may be initiated via autocrine, paracrine, and endocrine mechanisms, depending on the source of $\mathrm{Hh}$ ligands. ${ }^{1}$ After binding with $\mathrm{Hh}$ ligands, canonical $\mathrm{Hh}$ pathway activation requires Smo translocation to the primary cilium and results in Gli transcription factors entering into the nuclei to regulate gene expression. ${ }^{51}$ Primary cilium has two roles in $\mathrm{Hh}$ signaling: to receive $\mathrm{Hh}$ and to initiate signal transduction in responding cells. ${ }^{52}$ However, murine or human hepatocytes have no cilia. ${ }^{53}$ Furthermore, adult healthy hepatocytes have been found to express only a tiny amount of Hh ligands, ${ }^{27}$ Ptch and Gli1. ${ }^{18}$ In contrast, the nonparenchymal cells (including hepatic stellate cells and natural killer $\mathrm{T}$ cells) and cholangiocytes can produce $\mathrm{Hh}$ ligands. ${ }^{1}$ Thus, in the adult liver, Hh signaling is lower in hepatocytes compared with the nonparenchymal cells. Partly because of these distinct cellular features, research on Hh signaling in the adult liver has focused predominantly on nonparenchymal cells, with hepatocytes being largely neglected or even considered as nonresponding. ${ }^{27}$ In this context, a recent study describes that there is ciliaindependent but Smo-dependent signaling in mature healthy hepatocytes and Hh signaling is active in healthy mature hepatocytes. ${ }^{29}$ Herein, the Hh pathway was shown to be activated in hepatocytes in the setting of Fas-induced liver injury, as evidenced by enhanced expression of Smo,
Ptch1, and Gli1 in Jo2-treated control mice. Deletion of hepatocyte Smo enhanced Fas-induced apoptosis, both in vivo and in vitro. Hh signaling activation in hepatocytes seems to be an important adaptive response to counterbalance Fas-induced apoptosis and liver injury.

Hh signaling has been shown to activate NF- $\kappa \mathrm{B}$, and the effect has been reported to be dependent on Smo; however, whether Gli is required for NF- $\mathrm{B}$ activation appears to be context dependent. ${ }^{54,55}$ For example, in diffuse large B-cell lymphoma, Smo contributes to NF- $\kappa \mathrm{B}$ activation through recruiting G-protein subunits $\mathrm{G} \alpha \mathrm{i}$ and $\mathrm{G} \alpha 12{ }^{54}$ In pancreatic ductal adeonocarcinoma, Smo-mediated activation of Gli has been shown to regulate I- $\kappa-\mathrm{B}$ kinase $\varepsilon$, which leads to NF- $\kappa \mathrm{B}$ activation. $^{55}$ In our system, a reduced level of NF- $\kappa \mathrm{B}$ was observed in Jo2-treated Smo LKO mice compared with control mice, which supports the role of Smo for $\mathrm{NF}-\kappa \mathrm{B}$ activation in the liver. The role of $\mathrm{NF}-\kappa \mathrm{B}$ in mediating the effect of Smo in the liver is further supported by the finding that $\mathrm{NF}-\kappa \mathrm{B}$ overexpression prevented Fas-induced liver injury in Smo LKO mice. The exact mechanism by which Smo regulates $\mathrm{NF}-\kappa \mathrm{B}$ activity in the liver remains to be further defined.

In summary, the current study provides novel evidence that, in the setting of liver injury, hepatocytes undergo phenotype change with up-regulation of Smoothened, such that hepatocytes are switched from Hh-nonresponsive to Hh-responsive status. Our findings suggest that hepatocytes can become responsive to Hh ligands during liver injury and that activation of hepatocyte Hh signaling may be a key reactive response in hepatocyte survival and tissue repair.

\section{Supplemental Data}

Supplemental material for this article can be found at https://doi.org/10.1016/j.ajpath.2018.07.018.

\section{References}

1. Omenetti A, Choi S, Michelotti G, Diehl AM: Hedgehog signaling in the liver. J Hepatol 2011, 54:366-373

2. Jung Y, McCall SJ, Li YX, Diehl AM: Bile ductules and stromal cells express hedgehog ligands and/or hedgehog target genes in primary biliary cirrhosis. Hepatology 2007, 45:1091-1096

3. Omenetti A, Popov Y, Jung Y, Choi SS, Witek RP, Yang L, Brown KD, Schuppan D, Diehl AM: The hedgehog pathway regulates remodelling responses to biliary obstruction in rats. Gut 2008 , 57:1275-1282

4. Omenetti A, Yang L, Li YX, McCall SJ, Jung Y, Sicklick JK Huang J, Choi S, Suzuki A, Diehl AM: Hedgehog-mediated mesenchymal-epithelial interactions modulate hepatic response to bile duct ligation. Lab Invest 2007, 87:499-514

5. Sicklick JK, Li YX, Melhem A, Schmelzer E, Zdanowicz M, Huang J, Caballero M, Fair JH, Ludlow JW, McClelland RE, Reid LM, Diehl AM: Hedgehog signaling maintains resident hepatic progenitors throughout life. Am J Physiol Gastrointest Liver Physiol 2006, 290:G859-G870

6. Fleig SV, Choi SS, Yang L, Jung Y, Omenetti A, VanDongen HM, Huang J, Sicklick JK, Diehl AM: Hepatic accumulation of hedgehog- 
reactive progenitors increases with severity of fatty liver damage in mice. Lab Invest 2007, 87:1227-1239

7. Jung Y, Witek RP, Syn WK, Choi SS, Omenetti A, Premont R, Guy CD, Diehl AM: Signals from dying hepatocytes trigger growth of liver progenitors. Gut 2010, 59:655-665

8. Syn WK, Choi SS, Liaskou E, Karaca GF, Agboola KM, Oo YH, Mi Z, Pereira TA, Zdanowicz M, Malladi P, Chen Y, Moylan C, Jung Y, Bhattacharya SD, Teaberry V, Omenetti A, Abdelmalek MF, Guy CD, Adams DH, Kuo PC, Michelotti GA, Whitington PF, Diehl AM: Osteopontin is induced by hedgehog pathway activation and promotes fibrosis progression in nonalcoholic steatohepatitis. Hepatology 2011, 53:106-115

9. Chen Y, Choi SS, Michelotti GA, Chan IS, Swiderska-Syn M, Karaca GF, Xie G, Moylan CA, Garibaldi F, Premont R, Suliman HB, Piantadosi CA, Diehl AM: Hedgehog controls hepatic stellate cell fate by regulating metabolism. Gastroenterology 2012, 143:1319-1329.e1-11

10. Bohinc BN, Diehl AM: Mechanisms of disease progression in NASH: new paradigms. Clin Liver Dis 2012, 16:549-565

11. Syn WK, Agboola KM, Swiderska M, Michelotti GA, Liaskou E, Pang H, Xie G, Philips G, Chan IS, Karaca GF, Pereira Tde A, Chen Y, Mi Z, Kuo PC, Choi SS, Guy CD, Abdelmalek MF, Diehl AM: NKT-associated hedgehog and osteopontin drive fibrogenesis in non-alcoholic fatty liver disease. Gut 2012, 61:1323-1329

12. Choi SS, Syn WK, Karaca GF, Omenetti A, Moylan CA, Witek RP, Agboola KM, Jung Y, Michelotti GA, Diehl AM: Leptin promotes the myofibroblastic phenotype in hepatic stellate cells by activating the hedgehog pathway. J Biol Chem 2010, 285:36551-36560

13. Ochoa B, Syn WK, Delgado I, Karaca GF, Jung Y, Wang J, Zubiaga AM, Fresnedo O, Omenetti A, Zdanowicz M, Choi SS, Diehl AM: Hedgehog signaling is critical for normal liver regeneration after partial hepatectomy in mice. Hepatology 2010, 51: $1712-1723$

14. Guy CD, Suzuki A, Zdanowicz M, Abdelmalek MF, Burchette J, Unalp A, Diehl AM: Hedgehog pathway activation parallels histologic severity of injury and fibrosis in human nonalcoholic fatty liver disease. Hepatology 2012, 55:1711-1721

15. Syn WK, Oo YH, Pereira TA, Karaca GF, Jung Y, Omenetti A, Witek RP, Choi SS, Guy CD, Fearing CM, Teaberry V, Pereira FE, Adams DH, Diehl AM: Accumulation of natural killer T cells in progressive nonalcoholic fatty liver disease. Hepatology 2010, 51: $1998-2007$

16. Jung Y, Brown KD, Witek RP, Omenetti A, Yang L, Vandongen M, Milton RJ, Hines IN, Rippe RA, Spahr L, Rubbia-Brandt L, Diehl AM: Accumulation of hedgehog-responsive progenitors parallels alcoholic liver disease severity in mice and humans. Gastroenterology 2008, 134:1532-1543

17. Wang Y, Han C, Lu L, Magliato S, Wu T: Hedgehog signaling pathway regulates autophagy in human hepatocellular carcinoma cells. Hepatology 2013, 58:995-1010

18. Sicklick JK, Li YX, Jayaraman A, Kannangai R, Qi Y, Vivekanandan P, Ludlow JW, Owzar K, Chen W, Torbenson MS, Diehl AM: Dysregulation of the hedgehog pathway in human hepatocarcinogenesis. Carcinogenesis 2006, 27:748-757

19. Patil MA, Zhang J, Ho C, Cheung ST, Fan ST, Chen X: Hedgehog signaling in human hepatocellular carcinoma. Cancer Biol Ther 2006, 5:111-117

20. Huang S, He J, Zhang X, Bian Y, Yang L, Xie G, Zhang K, Tang W, Stelter AA, Wang Q, Zhang H, Xie J: Activation of the hedgehog pathway in human hepatocellular carcinomas. Carcinogenesis 2006, 27:1334-1340

21. Pereira Tde A, Witek RP, Syn WK, Choi SS, Bradrick S, Karaca GF, Agboola KM, Jung Y, Omenetti A, Moylan CA, Yang L, Fernandez-Zapico ME, Jhaveri R, Shah VH, Pereira FE, Diehl AM: Viral factors induce hedgehog pathway activation in humans with viral hepatitis, cirrhosis, and hepatocellular carcinoma. Lab Invest 2010, 90:1690-1703
22. Villanueva A, Newell P, Chiang DY, Friedman SL, Llovet JM: Genomics and signaling pathways in hepatocellular carcinoma. Semin Liver Dis 2007, 27:55-76

23. Philips GM, Chan IS, Swiderska M, Schroder VT, Guy C, Karaca GF, Moylan C, Venkatraman T, Feuerlein S, Syn WK, Jung Y, Witek RP, Choi S, Michelotti GA, Rangwala F, Merkle E, Lascola C, Diehl AM: Hedgehog signaling antagonist promotes regression of both liver fibrosis and hepatocellular carcinoma in a murine model of primary liver cancer. PLoS One 2011, 6:e23943

24. Alcedo J, Ayzenzon M, Von Ohlen T, Noll M, Hooper JE: The Drosophila smoothened gene encodes a seven-pass membrane protein, a putative receptor for the hedgehog signal. Cell 1996, 86: $221-232$

25. Shevde LA, Samant RS: Nonclassical hedgehog-GLI signaling and its clinical implications. Int J Cancer 2014, 135:1-6

26. Robbins DJ, Fei DL, Riobo NA: The hedgehog signal transduction network. Sci Signal 2012, 5:re6

27. Matz-Soja M, Hovhannisyan A, Gebhardt R: Hedgehog signalling pathway in adult liver: a major new player in hepatocyte metabolism and zonation? Med Hypotheses 2013, 80:589-594

28. Rangwala F, Guy CD, Lu J, Suzuki A, Burchette JL, Abdelmalek MF, Chen W, Diehl AM: Increased production of sonic hedgehog by ballooned hepatocytes. J Pathol 2011, 224:401-410

29. Matz-Soja M, Aleithe S, Marbach E, Bottger J, Arnold K, SchmidtHeck W, Kratzsch J, Gebhardt R: Hepatic hedgehog signaling contributes to the regulation of IGF1 and IGFBP1 serum levels. Cell Commun Signal 2014, 12:11

30. Chen W, Han C, Zhang J, Song K, Wang Y, Wu T: miR-150 deficiency protects against FAS-induced acute liver injury in mice through regulation of AKT. PLoS One 2015, 10:e0132734

31. Li WC, Ralphs KL, Tosh D: Isolation and culture of adult mouse hepatocytes. Methods Mol Biol 2010, 633:185-196

32. Choi SS, Omenetti A, Witek RP, Moylan CA, Syn WK, Jung Y, Yang L, Sudan DL, Sicklick JK, Michelotti GA, Rojkind M, Diehl AM: Hedgehog pathway activation and epithelial-tomesenchymal transitions during myofibroblastic transformation of rat hepatic cells in culture and cirrhosis. Am J Physiol Gastrointest Liver Physiol 2009, 297:G1093-G1106

33. Huh CG, Factor VM, Sanchez A, Uchida K, Conner EA, Thorgeirsson SS: Hepatocyte growth factor/c-met signaling pathway is required for efficient liver regeneration and repair. Proc Natl Acad Sci U S A 2004, 101:4477-4482

34. Feldstein AE, Canbay A, Angulo P, Taniai M, Burgart LJ, Lindor KD, Gores GJ: Hepatocyte apoptosis and fas expression are prominent features of human nonalcoholic steatohepatitis. Gastroenterology 2003, 125:437-443

35. Hatano E, Bennett BL, Manning AM, Qian T, Lemasters JJ, Brenner DA: NF-kappaB stimulates inducible nitric oxide synthase to protect mouse hepatocytes from TNF-alpha- and Fas-mediated apoptosis. Gastroenterology 2001, 120:1251-1262

36. Li G, Chen W, Han C, Wu T: Cytosolic phospholipase A(2)alpha protects against Fas- but not LPS-induced liver injury. J Hepatol 2011, 55:1281-1290

37. Li P, Jayarama S, Ganesh L, Mordi D, Carr R, Kanteti P, Hay N, Prabhakar BS: Akt-phosphorylated mitogen-activated kinase-activating death domain protein (MADD) inhibits TRAIL-induced apoptosis by blocking Fas-associated death domain (FADD) association with death receptor 4. J Biol Chem 2010, 285: 22713-22722

38. Hatano E, Brenner DA: Akt protects mouse hepatocytes from TNFalpha- and Fas-mediated apoptosis through NK-kappa B activation. Am J Physiol Gastrointest Liver Physiol 2001, 281:G1357-G1368

39. Jones RG, Elford AR, Parsons MJ, Wu L, Krawczyk CM, Yeh WC, Hakem R, Rottapel R, Woodgett JR, Ohashi PS: CD28-dependent activation of protein kinase B/Akt blocks Fas-mediated apoptosis by preventing death-inducing signaling complex assembly. J Exp Med 2002, 196:335-348 
40. Gingras AC, Kennedy SG, O’Leary MA, Sonenberg N, Hay N: 4E-BP1, a repressor of $\mathrm{mRNA}$ translation, is phosphorylated and inactivated by the Akt(PKB) signaling pathway. Genes Dev 1998, 12:502-513

41. Liu F, Song Y, Liu D: Hydrodynamics-based transfection in animals by systemic administration of plasmid DNA. Gene Ther 1999, 6 : $1258-1266$

42. Zhang G, Budker V, Wolff JA: High levels of foreign gene expression in hepatocytes after tail vein injections of naked plasmid DNA. Hum Gene Ther 1999, 10:1735-1737

43. Tsoulfas G, Takahashi Y, Liu D, Yagnik G, Wu T, Murase N, Geller DA: Hydrodynamic plasmid DNA gene therapy model in liver transplantation. J Surg Res 2006, 135:242-249

44. Fox CK, Furtwaengler A, Nepomuceno RR, Martinez OM, Krams SM: Apoptotic pathways in primary biliary cirrhosis and autoimmune hepatitis. Liver 2001, 21:272-279

45. Rivero M, Crespo J, Fabrega E, Casafont F, Mayorga M, GomezFleitas M, Pons-Romero F: Apoptosis mediated by the Fas system in the fulminant hepatitis by hepatitis B virus. J Viral Hepat 2002, 9:107-113

46. Ogasawara J, Watanabe-Fukunaga R, Adachi M, Matsuzawa A, Kasugai T, Kitamura Y, Itoh N, Suda T, Nagata S: Lethal effect of the anti-Fas antibody in mice. Nature 1993, 364:806-809

47. Lapinski TW, Kowalczuk O, Prokopowicz D, Chyczewski L: Serum concentration of sFas and sFasL in healthy HBsAg carriers, chronic viral hepatitis B and C patients. World J Gastroenterol 2004, 10:3650-3653

48. Taieb J, Mathurin P, Poynard T, Gougerot-Pocidalo MA, CholletMartin S: Raised plasma soluble Fas and Fas-ligand in alcoholic liver disease. Lancet 1998, 351:1930-1931
49. Rutherford AE, Hynan LS, Borges CB, Forcione DG, Blackard JT, Lin W, Gorman AR, Shaikh OS, Reuben A, Harrison E, Reddy KR, Le WM, Chung RT; ALF Study Group: Serum apoptosis markers in acute liver failure: a pilot study. Clin Gastroenterol Hepatol 2007, 5: $1477-1483$

50. Ryo K, Kamogawa Y, Ikeda I, Yamauchi K, Yonehara S, Nagata S, Hayashi N: Significance of Fas antigen-mediated apoptosis in human fulminant hepatic failure. Am J Gastroenterol 2000, 95:2047-2055

51. Grzelak CA, Martelotto LG, Sigglekow ND, Patkunanathan B Ajami K, Calabro SR, Dwyer BJ, Tirnitz-Parker JE, Watkins DN, Warner FJ, Shackel NA, McCaughan GW: The intrahepatic signalling niche of hedgehog is defined by primary cilia positive cells during chronic liver injury. J Hepatol 2014, 60:143-151

52. Kornberg TB: The contrasting roles of primary cilia and cytonemes in Hh signaling. Dev Biol 2014, 394:1-5

53. Grisham JW, Nopanitaya W, Compagno J, Nagel AE: Scanning electron microscopy of normal rat liver: the surface structure of its cells and tissue components. Am J Anat 1975, 144:295-321

54. Qu C, Liu Y, Kunkalla K, Singh RR, Blonska M, Lin X, Agarwal NK, Vega F: Trimeric G protein-CARMA1 axis links smoothened, the hedgehog receptor transducer, to NF-kappaB activation in diffuse large B-cell lymphoma. Blood 2013, 121:4718-4728

55. Rajurkar M, De Jesus-Monge WE, Driscoll DR, Appleman VA, Huang H, Cotton JL, Klimstra DS, Zhu LJ, Simin K, Xu L, McMahon AP, Lewis BC, Mao J: The activity of Gli transcription factors is essential for Kras-induced pancreatic tumorigenesis. Proc Natl Acad Sci U S A 2012, 109:E1038-E1047 